\title{
The Utility of Double Opposing Transposition Flaps in the Management of Inguinal Ectopic Scrotum: Surgical Experience and Literature Review
}

\author{
Anas Alyamani ${ }^{1,2}$, Feras Alshomer ${ }^{1,2}$, Fayez Almodhen ${ }^{3,2}$, Obaid Almeshal ${ }^{1,2}$ \\ 1. Plastic and Reconstructive Surgery, Surgery Department, King Abdulaziz Medical City, National Guard's Health \\ Affairs, Riyadh, SAU 2. Surgery, King Abdullah International Medical Research Center, Riyadh, SAU 3. Pediatric \\ Urology Section, Surgery Department, King Abdulaziz Medical City, National Guard's Health Affairs, Riyadh, SAU
}

Corresponding author: Feras Alshomer, dr.fshomer@gmail.com

\begin{abstract}
An ectopic scrotum (ES) represents a rare developmental anomaly of the male genitalia. The condition usually represents a part of a wide spectrum pathology associated with other anomalies. The different locations in which an ectopic scrotum is found include inguinal, suprainguinal, infrainguinal, and/or perineum. There are several surgical techniques described in the literature related to the management of ES, but none of them showed superior results. We present a rare case of ectopic hemiscrotum managed as part of a multidisciplinary team approach, showing the utility of double opposing transposition z-plasty flaps in managing such a case.
\end{abstract}

Review began 02/26/2021 Review ended 03/13/2021 Published 03/19/2021

() Copyright 2021

Alyamani et al. This is an open access article distributed under the terms of the Creative Commons Attribution License CC-BY 4.0., which permits unrestricted use, distribution, and reproduction in any medium, provided the original author and source are credited.
Categories: Pediatric Surgery, Plastic Surgery, Urology

Keywords: ectopic, scrotum, inguinal, z-plasty, flap, reconstruction

\section{Introduction}

Various congenital anomalies that affect scrotal development might include bifid scrotum, penoscrotal transposition, accessory scrotum, or even ectopic scrotum [1]. An ectopic scrotum (ES) represents a rare developmental anomaly that usually comes with other anomalies that affect the male genitalia. ES can be in different locations, but most are usually located in the inguinal, suprainguinal, infrainguinal, or perineal area. Associated anomalies include inguinal hernia, cryptorchidism, and exstrophy of the bladder [2,3]. We present a rare case of ectopic hemiscrotum associated with hypospadias and penile torque managed by a multidisciplinary team involving plastic surgery, urology, and pediatrics.

\section{Case Presentation}

A full-term one-month-old baby presented to the clinic with unremarkable perinatal history. Physical examination showed left inguinal hemiscrotum. The right half of the scrotum was developed normally with a normal testicle in position. The ectopic hemiscrotum was in the inguinal area with a smaller testicle but within the normal variation. He had penile torque and hypospadias (Figure 1). Renal ultrasound was normal, while cystourethrogram showed grade 1 vesicoureteric reflux with minimal opacification of the distal left ureter. Chromosomal analysis showed a normal male karyotype. 


\section{Cureus}

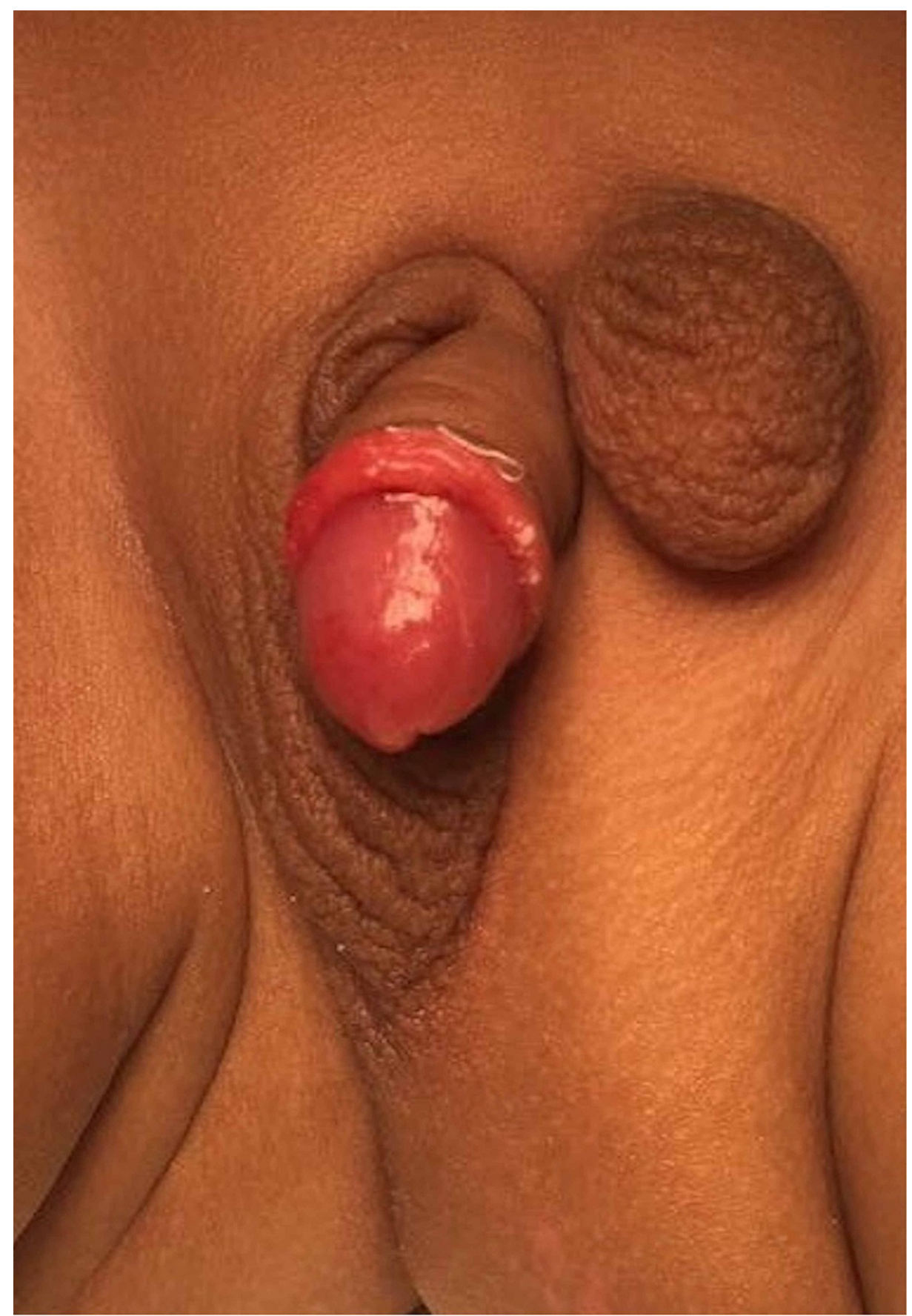

\section{FIGURE 1: Pre-operative photo}

The photo shows the left inguinal ectopic hemiscrotum with associated hypospadias and penile torque.

The patient was treated by a multidisciplinary team approach that involved plastic surgery, urology, and pediatrics. The patient underwent scrotoplasty, correction of the penile torque, and hypospadias at the age of thirteen months. The scrotoplasty was done utilizing the z-plasty principle with double transposition flaps. The upper flap based inferiorly containing the scrotum and the testicle was mobilized as a block after freeing the spermatic cord and then sutured to the side of the adjacent scrotum. The lower flap utilizing the skin between the two scrotii based superiorly was transported to fill the defect in the inguinal region and to minimize the penile torque deformity. The vascularity of the left hemiscrotum was maintained with no risk of testicular torsion. Subcoronal hypospadias repair was done with a stent kept place (Snodgrass hypospadias repair) (Figure 2). 


\section{Cureus}

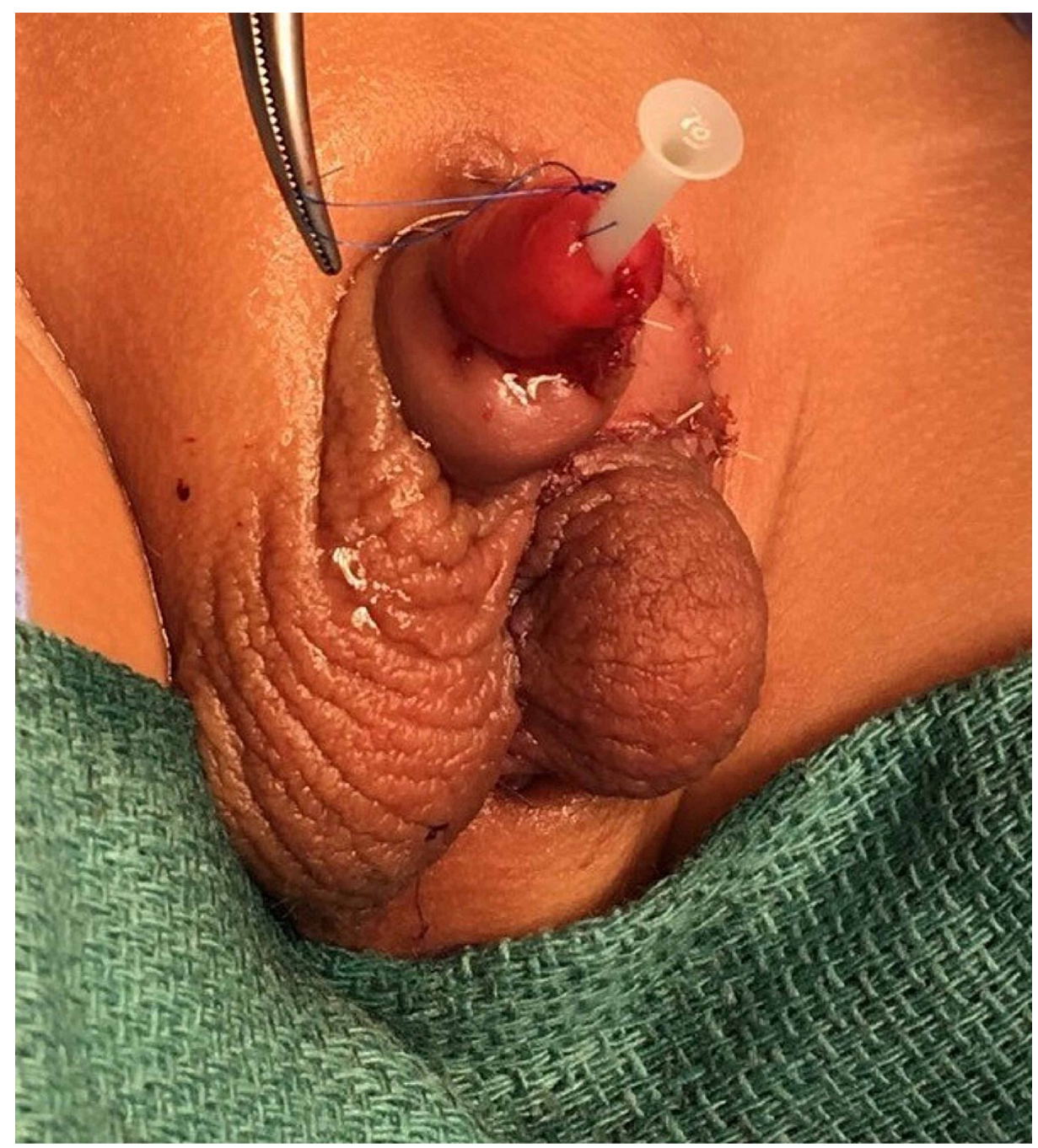

\section{FIGURE 2: Post-operative results}

The photo shows the repaired ectopic hemiscrotum after block unit mobilization with the use of double opposing transposition z-plasty flap with the repair of hypospadias and penile torque, with a stent in place.

The patient was followed up in the clinic with a good surgical outcome, no complications, and the parents were satisfied with the result (Figure 3). The patient's parents consented to share the information related to this manuscript. 


\section{Cureus}

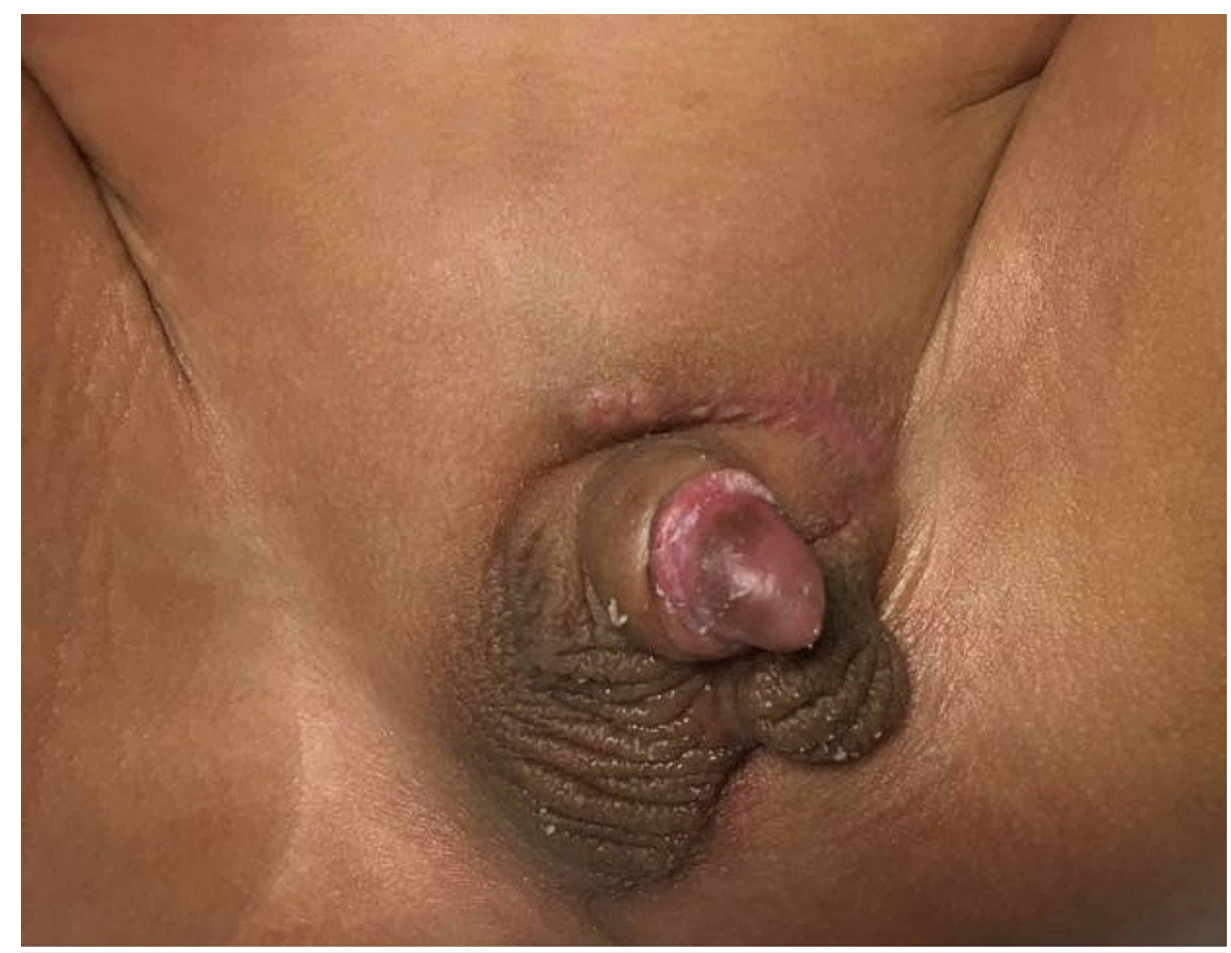

\section{FIGURE 3: Follow-up assessment}

The photo shows the results after two months follow-up, with a satisfactory position of the mobilized ectopic hemiscrotum.

\section{Discussion}

The development of the scrotum is well explained in the literature. However, scrotal anomalies are quite ubiquitous. A brief explanation of the normal development of the scrotum starts with an appearance of two labiosacral swellings at four weeks of gestation lateral to the cloacal membrane. At week 12 , the two labiosacral swellings grow and fuse to form the scrotum. The line along the fusion is called the raphe mediana. At the same time, the gubernaculum plays a major role in the descent of the testis by inserting into the labiosacral swelling [4]. However, the embryological explanation of the ectopic scrotum is not known. In this case, the testis was misdirected into the inguinal area with a normal variant testis.

Reviewing the literature shows that inguinal ectopic scrotum is mostly associated with other developmental anomalies that may include and are not limited to cryptorchidism, renal agenesis, penile torsion, hypospadias, renal dysplasia, and testicular atrophy [5]. In our case, the patient, as mentioned, also had associated hypospadias and penile torque, which were corrected in the same procedure with a satisfactory outcome.

Different surgical methods have been described in the literature related to the management of ES, as summarized in (Table 1). Briefly, such techniques might include excision of the ectopic hemiscrotum with mobilization of the testis into the opposite hemiscrotum as described by Elder and Jeffs (1982) and Guha (1979) [6,7]. Sobral Filho et al. described an inverted Y incision that utilizes the perineal skin flaps in the scrotal sac reconstruction [8]. Lamm and Kaplan described a method in which the ES was brought into the normal position and sutured to the lateral aspect of the normotopic scrotum by a rotation flap [9]. The utility of z-plasty in scrotoplasty was sparsely evaluated in recent literature, in which most of its use was in a staged approach to correct any residual associated deformities [10]. In this case, we showed the great potential utility of double opposing transpositional flaps with the mobilization of the ectopic scrotum as a whole block with a great satisfactory outcome. 


\section{Cureus}

\begin{tabular}{|c|c|c|c|}
\hline Author & Patient & Repair Technique & Outcome \\
\hline $\begin{array}{l}\text { Lamm } \\
1977[9]\end{array}$ & $\begin{array}{l}\text { Case 1: ectopic left inguinal scrotum } \\
\text { with a deviation of the penis to right. } \\
\text { Case 2: ectopic right inguinal scrotum } \\
\text { as well as normotopic scrotum } \\
\text { containing palpably normal testes. }\end{array}$ & $\begin{array}{l}\text { The ectopic scrotum was used } \\
\text { for skin coverage of the penis } \\
\text { by rotating it down to the } \\
\text { midline. }\end{array}$ & $\begin{array}{l}\text { Wound infection with later skin } \\
\text { contracture. Staged reconstruction was } \\
\text { performed with the utility of z-plasty to } \\
\text { correct the scarring at the base of the } \\
\text { penis and to reposition the deviated penis. }\end{array}$ \\
\hline $\begin{array}{l}\text { Guha } \\
1979[7]\end{array}$ & $\begin{array}{l}\text { Congenital absence of the left half of } \\
\text { the scrotum with a small sac of scrotal } \\
\text { skin in the left inguinal region. }\end{array}$ & $\begin{array}{l}\text { Excision of the ectopic } \\
\text { hemiscrotum with mobilization } \\
\text { of the testis into the opposite } \\
\text { hemiscrotum }\end{array}$ & Not mentioned \\
\hline $\begin{array}{l}\text { Elder } \\
1982[6]\end{array}$ & Supra-inguinal ectopic scrotum & $\begin{array}{l}\text { Excision of the ectopic } \\
\text { hemiscrotum with mobilization } \\
\text { of the testis into the opposite } \\
\text { hemiscrotum }\end{array}$ & Not mentioned \\
\hline $\begin{array}{l}\text { Gunaydin } \\
1997[11]\end{array}$ & $\begin{array}{l}\text { Right side: inguinal ectopic scrotum. } \\
\text { Left side: in normal position. Each } \\
\text { hemiscrotum was containing testis. }\end{array}$ & $\begin{array}{l}\text { A pedicled flap raised in } \\
\text { between the ectopic and } \\
\text { normal scrotum, then it was } \\
\text { mobilized laterally and sutured } \\
\text { to the ectopic scrotum lateral } \\
\text { side. }\end{array}$ & No complication \\
\hline $\begin{array}{l}\text { Daniel } \\
2015 \text { [12] }\end{array}$ & $\begin{array}{l}\text { Right inguinal ectopic scrotum } \\
\text { containing the testis. The ectopic } \\
\text { scrotal skin had a small central skin tag. } \\
\text { There was intervening normal skin } \\
\text { between the two halves of his scrotum. }\end{array}$ & rotation flap & No complication \\
\hline $\begin{array}{l}\text { Sobral } \\
\text { Filho } \\
2017[8]\end{array}$ & $\begin{array}{l}\text { Bilateral cryptorchidism with ectopic } \\
\text { penis and scrotum found in perineal } \\
\text { area. }\end{array}$ & $\begin{array}{l}\text { Scrotal skin flaps in the } \\
\text { perineum were utilized in the } \\
\text { reconstruction of scrotal sac } \\
\text { with the utility of inverted } Y \\
\text { shaped incision }\end{array}$ & No complication \\
\hline $\begin{array}{l}\text { Hisamatsu } \\
2019 \text { [13] }\end{array}$ & $\begin{array}{l}\text { Right infrainguinal hemiscrotum with } \\
\text { testis within the sac. }\end{array}$ & Rotation flap scrotoplasty & No complication \\
\hline
\end{tabular}

TABLE 1: Summary of different surgical techniques described in the literature that are related to the management of ES

Despite the many techniques described to deal with an ectopic scrotum, there was no definitive technique superior to others. The unique aspect of this case is that the scrotoplasty approach was different than the usual approach; here, the whole scrotum and the testis were mobilized as a block, as previously explained. Further, follow-up showed a good outcome with an acceptable functional and aesthetic result.

\section{Conclusions}

An ectopic scrotum (ES) represents a rare developmental anomaly of the male genitalia. Such a condition is usually accompanied by other congenital defects such as hypospadias and penile torque, as seen in our case. We described a reconstructive technique that utilizes local tissue rearrangement with the utility of double opposing transposition z-plasty flaps to reconstruct the malpositioned scrotum with an excellent functional outcome with long-term follow-ups.

\section{Additional Information}

\section{Disclosures}

Human subjects: Consent was obtained or waived by all participants in this study. Conflicts of interest: In compliance with the ICMJE uniform disclosure form, all authors declare the following: Payment/services info: All authors have declared that no financial support was received from any organization for the submitted work. Financial relationships: All authors have declared that they have no financial relationships at present or within the previous three years with any organizations that might have an 
interest in the submitted work. Other relationships: All authors have declared that there are no other relationships or activities that could appear to have influenced the submitted work.

\section{References}

1. MacDonald MF, Barthold JS, Kass EJ: Abnormalities of the penis and scrotum. Clinical Pediatric Urology. Docimo SG, Canning DA, Khoury AE (ed): Informa Healthcare, UK; 2007. 1246. 10.1201/b13795

2. Wahyudi I, Deswanto IA, Situmorang GR, Rodjani A: One stage rotation flap scrotoplasty and orchidopexy for the correction of ectopic scrotum: a case report. Urol Case Rep. 2019, 25:100886.

10.1016/j.eucr.2019.100886

3. Gardikis S, Kambouri K, Tsalkidis A, Angelidou M, Pitiakoudis M, Vaos G: Inguinal ectopic scrotum in a neonate: case report and literature review. Pediatr Int. 2012, 54:575-576. 10.1111/j.1442-200X.2012.03656.X

4. Hoar RM, Calvano CJ, Reddy PP, Bauer SB, Mandell J: Unilateral suprainguinal ectopic scrotum: the role of the gubernaculum in the formation of an ectopic scrotum. Teratology. 1998, 57:64-69. 10.1002/(SICI)10969926(199802)57:2<64::AID-TERA4>3.0.CO;2-6

5. Spears T, Franco I, Reda EF, Hernandez-Graulau J, Levitt SB: Accessory and ectopic scrotum with VATER association. Urology. 1992, 40:343-345. 10.1016/0090-4295(92)90385-a

6. Elder JS, Jeffs RD: Suprainguinal ectopic scrotum and associated anomalies. J Urol. 1982, 127:336-338. 10.1016/S0022-5347(17)53769-6

7. Guha SC: Unilateral ectopic scrotum. Br J Plast Surg. 1979, 32:91-92. 10.1016/0007-1226(79)90003-1

8. Sobral Filho DS, da Silva HD, Damázio E: Surgical correction of ectopic penis and scrotum associated with bilateral orchidopexy. Einstein (Sao Paulo). 2017, 15:223-225. 10.1590/S1679-45082017RC3927

9. Lamm DL, Kaplan GW: Accessory and ectopic scrota. Urology. 1977, 9:149-153. 10.1016/00904295(77)90185-6

10. Williams DW: Anomaly of scrotum and testes: simple plastic repair . J Urol. 1963, 89:860-863. 10.1016/s0022-5347(17)64663-9

11. Günaydin M, Aritürk E, Rizalar R, Görk S, Bernay F, Gürses N: Unilateral inguinal ectopic scrotum and imperforate anus: a case report. J Pediatr Surg. 1997, 32:1360-1361. 10.1016/S0022-3468(97)90322-5

12. Daniel G, Coleman R: Staged rotation flap scrotoplasty and orchidopexy in a patient with inguinal ectopic scrotum. J Surg Case Rep. 2015, 2015:rjv137. 10.1093/jscr/rjv137

13. Hisamatsu E, Shibata R, Yoshino K: Surgical correction of ectopic scrotum and penile torsion in a 5-year-old boy. Indian J Urol. 2019, 35:299-300. 10.4103/iju.IJU_160_19 